\title{
Developing green marketing tourism in Perak, Malaysia
}

\author{
Hengky Sumitso Halim ${ }^{1}$, Zhang Qian nan², Miraj Ahmed Bhuiyan ${ }^{3 *}$ \\ ${ }^{1}$ Bina Darma University Palembang, Sumatera Selatan, Indonesia \\ ${ }^{2,3}$ Guangdong University of Finance \& Economics. 21 Luntou road, Guangzhou, Guangdong China
}

\begin{abstract}
Perak is the second largest state in Malaysia. Meanwhile, the trend of tourists to Perak has declined. The local government is working with the Ministry of Tourism, Arts and Culture to increase the number of tourists for the Visit Malaysia 2020 program. They focus on campaigning for markets: Europe, Australia, the Middle East, Central and East Asia. Meanwhile, environmental health problems worsen the quality of tourist destinations in Perak. To respond to this program, they are trying to increase a tourist visits by conducting a Silver Tourism promotion campaign that uses English and Chinese as part of its marketing strategy. The aim is to increase the attractiveness of tourists from Europe and China. We recommend paying attention to social influences, environmental awareness, pro-environment behavior, and awareness of pro-environment behavior. By paying attention and building this empathy, it will prepare the application of green marketing strategy.
\end{abstract}

\section{Introduction}

In 2016, tourist arrivals in Malaysia were 25 million and tourism sector's contribution to the economy was about RM 62 billion, whereas in 2015 its economic contribution was about RM 55 billion.

Therefore, this study also responds to the promotion of tourism in Perak heritage theme by the director of the new Tourism Malaysia Perak that will use a new marketing strategy. Previously, he planned to use to greet the Visit Malaysia 2014 (RM, 2013). In addition, this study also responds Tourism Perak Bhd CEO statement stating that the Ipoh City held cultural tourism.

Due to the decreasing number of tourists, the Ministry of Tourism, Arts and Culture is looking for a new tourism target market with a target of 30 million tourists to Visit Malaysia 2020. The campaign is to focus on the tourism market in European countries, Australia, the Middle East, Central Asia, Russia and Asia East like Japan and South Korea (Tong, 2020) [1]. While, the main environmental problems of Malaysia are illegal mining, dam projects, sewage disposal projects, water leakage, and logging projects. In addition, the activity of burning waste, processing industrial waste and river-pollution exacerbates the negative environmental impact. Economic growth of this country also causes air pollution and pollution from agricultural and livestock industries. The growth of tourism also contributed to the negative environmental impacts due to tourism activities, both in the form of trash from restaurants and waste from hotels. Oil waste pollutes some of the waters along the coast (Hays, 2015; JAG, 2011)[2,3]. However, green marketing tourism in Malaysia reached the level of corporate social responsibility. It need a higher attainment that will provide high impact on the protected environment, socio- economic, and policy (Farsa, 2012)[4]. The effort is in dearer by NGOs to implement conservation programs in Perak.

The aim of this study is to develop the destination in supporting green marketing and at the same time it could conserve the environment.

\section{Literature review}

\subsection{Green Marketing}

The green tourism marketing in the form of cultural truth in a commercial environment friendly green tourism which has an eco-label product. Moreover, green tourism is marketing as an integrated management of the supply chain of green tourism marketing, planning, promotion, processes, and people involved in the project. Meanwhile, implementing green tourism marketing, tourism company in this case is a tour operator duly realize that marketing of green travel market will generate positive results, and will generate important implications for managers in their efforts to have the support of top management for their green tourism marketing program (Dangelico \& Vocalelli, 2017a; Duffett, Edu, Haydam, Negricea, \& Zaharia, 2018; Groening, Sarkis, \& Zhu, 2018; Nedumaran \& M, 2020; Rahbar \& Wahid, 2011; \& Webster, 2020; Tsai et al., 2020) [5-11]. Furthermore, green tourism marketing related to sustainable tourism, as well as awareness among tourists about marketing green tourism services of the local communities that are environmentally friendly (Cui, Guo, \& Zhang, 2020; Khan, Royhan, Rahman, Rahman, \& Mostafa, 2020; Papadas, Avlonitis, \& Carrigan, 2017; Papadopoulos, Karagouni, Trigkas, \& Platogianni, 2010; Stafford \& Graul, 2020; Szabo \& Webster, 2020). [12$16,10]$

\footnotetext{
* Corresponding author: ahmed.miraz@qq.com
} 
Previously, explains both results and exchange facilities to meet the needs of tourists, and their expectations of minimal impact on the natural environment for their traveling. Similarly, promoting good public policy process and issue value of the program as a green tourism destination greening program by the company or tour operator with minimum environmental degradation. Furthermore, green marketing segment as a segment of the tourists, who are more interested in sustainable tourism, compared to mass tourism trends that will grow with its own (Syaekhoni, Alfian, \& Kwon, 2017)[17].

However, the concept of green marketing (Dangelico \& Vocalelli, 2017b; Mokha, 2017; Mukonza \& Swarts, 2020; P. Singh, Singh, \& Sharma, 2016)[18-21] meets the requirements: Social influence; Environmental-concern; pro-environment behavior; and awareness and proenvironment behavior.

\subsection{Social influence}

Social influence is a direct assessment of the price supporting green marketing that includes the influence of other people that are relevant and in a larger context, namely, the influence of the organization decision. There are two tactics of social influence, namely reciprocal relations and social evidence, which are used to increase the influence of societal orientation behavior that results in synergistic potential for their feeling and highlight of their directions of social impacts (Argo \& Dahl, 2020; Baumann, Lorenz-Spreen, Sokolov, \& Starnini, 2020; Higgs \& Ruddock, 2020; Hsu \& Lin, 2008; Koskinen \& Daraganova, 2020; Meoli, Fini, Sobrero, \& Wiklund, 2020; Muthukrishna \& Schaller, 2020; Ni, Yang, \& Kong, 2020; Pan, He, \& Yu, 2020a; Ramos, Boratto, \& Caleiro, 2020; Roethke, Klumpe, Adam, \& Benlian, 2020; N. Singh, Sinha, \& Liébana-Cabanillas, 2020; Weiß, Mussel, \& Hewig, 2020; Young, 2009)[22-35].

The type of influence of a green marketing tourism phenomenon that requires a lot of different influences suitability. While, social influence of marketing green tourism as defined in the form: individual-thinking that influenced by an individual or group (Efferson, Vogt, \& Fehr, 2020; Koskinen \& Daraganova, 2020; Pan, He, \& Yu, 2020b; N. Singh et al., 2020). [36,37], [26] The factors that increase the likelihood of a person in response to social influence (Abu-Salih et al., 2020; Chouchani \& Abed, 2020) in marketing green tourism are: (a) the strength of the individual that influence sustainable tourism section, (b) physical approach and the influence of environment friendly in their tourism business, and (c) the groups involved in it.

\subsection{Environmental concern}

The factors affecting green consumption patterns affect the environmental responsibility for consumers on green consumption and are related to its problems that affect price sensitivity, because consumers are concerned with their responsibility. This responsibility encourages them to reduce their negative environmental impacts. The development of environmental degradation interacts with the socio-economic status of individuals to have an impact on environmental concerns. People with better economic conditions generally have higher environmental awareness (Bian, Zhang, \& Zhou, 2020a; Bourliva, Papadopoulou, da Silva, \& Patinha, 2020; Campos-Soria, Núñez-Carrasco, \& García-Pozo, 2020; Chuah, ElManstrly, Tseng, \& Ramayah, 2020; Hao \& Song, 2020; Harmooshi, Shirbandi, \& Rahim, 2020; J. Kim, Tanaka, \& Schmöcker, 2020; Milfont, Poortinga, \& Sibley, 2020; Nguyen et al., 2020; Weber, Büssing, Jarzyna, \& Fiebelkorn, 2020; Yang, Ji, \& Tan, 2020; Yue, Sheng, She, $\& \mathrm{Xu}, 2020)[38-51]$. Environmental concern (Bian, Zhang, \& Zhou, 2020b; Cruz \& Manata, 2020; Franzen \& Mader, 2020; Rodrigo-Comino, 2020)[52-55] affects product of the green marketing tourism by utilizing the theory of planned behavior to the behavior. While, trading decisions of green marketing. Suki assess and realize that $25 \%$ of the price and the brand image of the tourists will significantly influence their decisions. Previously, the environmental concerns is an important factor green (Ma \& He, 2020; Rizkalla \& Erhan, 2020)[56,57].

\subsection{Pro-environmental behavior}

The belief that collective behavior benefits people and their participation affects pro-environmental behavior. Reflections on morals and social partners who support them concern for the environment significantly and positively affect the commitment to environmental sustainability. Their pro-environmental peered advocacy and environmental commitment influence their proenvironmental behavior collectively ( Denzin, 2012, Afsar \& Umrani, 2020; Fu et al., 2020; Hamann \& Reese, 2020; Kaaronen \& Strelkovskii, 2020; M. S. Kim \& Stepchenkova, 2020; Shafiei \& Maleksaeidi, 2020; Vesely, Klöckner, \& Brick, 2020; Xu, Huang, \& Whitmarsh, 2020)[58-66]. Pro-environmental behavior supporting green place (distribution) of the green marketing. It developed from self-image in the business of protecting the environment of sustainable tourism as purchase behavior of green or eco-friendly. Transaction behavior of green tourism marketing is consumer-friendly product that promotes minimal environmental impact or environmental protection, recyclable, ecological concerns sensitive or responsive to sustainable tourism (Binder, Blankenberg, \& Guardiola, 2020; Chwialkowska, Bhatti, \& Glowik, 2020; Cleveland, Robertson, \& Volk, 2020; Fu et al., 2020; Gong et al., 2020; Hoffmann \& Muttarak, 2020; Kautish \& Sharma, 2020a; Lee, Sung, Wu, Ho, \& Chiou, 2020; Liobikiené, Liobikas, Brizga, \& Juknys, 2020; Quoquab, Mohammad, \& Shahrin, 2020a; Wong, Wan, Huang, \& Qi, 2020; Yuriev, Dahmen, Paillé, Boiral, \& Guillaumie, 2020)[67-77].

Meanwhile, the green tourism marketing over the factors that influence the buying behavior of green tourism. The young travelers in Hong Kong 'has been using seven variables in the context of marketing green tourism: Tourism eco-friendly attitude; Awareness of the negative environmental impacts of tourism; Perceived seriousness of the negative environmental impacts of tourism; 
Perceived need for environmentally responsible tourism; Pro-environmental behavioral effectiveness environment; Awareness of the image in green marketing (Binder et al., 2020; $\mathrm{Fu}$ et al., 2020; Zibarras \& Coan, 2015).[67],[60],[78].

\subsection{Awareness and pro-environmental behavior}

Conducting green marketing tourism needs a people engage in behaviors that support environmentally friendly programs, and the tourists will participate on contributing to the program of environmental. Meanwhile, awareness and pro-environmental behavior (APEB) among tourists in supporting green promotion of green marketing. An environmental management program has a significant relationship with their responsibilities in environmental protection programs and also required the effectiveness of their behavior in environmental management. It will be more profitable in implementing the program of green tourism marketing (Fu et al., 2020).[60]

Moreover, the most important thing in predicting adolescent tourists' behavior at the time they make a purchase in the green tourism marketing program. This suggests that the green marketing tourism impacts on a social influence, concern for environmental management, a concern with self-image in the protection of the environment, and the perceived effectiveness of their behavior towards environmental protection $(\mathrm{Fu}$ et al., 2020; Gabarda-Mallorquí, Fraguell, \& Ribas, 2018).[60], [79].

However, the behavior of the tourists effectiveness in marketing green tourism, and he found an effective relationship between finite ecological component of the cost of environmentally friendly management and credibility associated with sustainable tourism, will affect the commitment of tourists in support of environmentally friendly management (Chen \& Cai, 2019; Dopelt, Radon, \& Davidovitch, 2019) [80],[81].

\section{Research method}

This study mixed mode (Denzin, 2012)[58] starting with a pre-research and it conducted in July 2018 - July 2019, in a year Perak. 180 of 220 respondents returned questionnaires. It is about

SI, EC, PEB, and APEB. Nevertheless, 20 of them are experts on SI, EC, PEB, and APEB. This study developed five (5) groups discussion (Nyumba, Wilson, Derrick, \& Mukherjee, 2018)[82]. They discussed (Table 1) about Breathtaking Belum, Bukit Larut, Teluk Batik, Pangkor Island, Pasir Bogak Beaches.

Table 1: Respondent of Focus Group Discussions

\begin{tabular}{|l|l|}
\hline $\begin{array}{l}\text { Each Group Discussions' } \\
\text { Topics (SI, PEB, EC, APEB) }\end{array}$ & $\begin{array}{l}\text { Number of } \\
\text { respondents } \\
\text { include experts }\end{array}$ \\
\hline Breathtaking Belum & 50 \\
\hline Bukit Larut & 50 \\
\hline Teluk Batik & 50 \\
\hline Pangkor Island & 50 \\
\hline
\end{tabular}

\begin{tabular}{|c|l|}
\hline Pasir Bogak Beach & 50 \\
\hline Each group consisted of 46 respondents that discuss
\end{tabular} about SI, ED, PEB, and APEB. The respondents from local government agencies to Department of tourism, local communities, tour operators, tourists, Tour and travel agencies, Restaurant staff, Taxi and Bus drivers, and Tour guide. Nevertheless, 180 respondents returned the questionnaires steadfastly.

The data tabulated by using SAS/STAT (SAS Institute Inc., NC, USA). The factors that affect the interaction of the interview, their opinion, current situations conducting interviews, and interview topics. The value $\mathrm{K}>0.6$ indicated the performance met the minimum requirements (Archibald, 2016; Denzin, 2012; Hengky, 2015; Mukonza \& Swarts, 2020)[83], [58],.[84], [20]

Based on the requirement, the analysis used a content analysis (Tiggemann \& Zaccardo, 2018; Vaismoradi, Turunen, \& Bondas, 2013)[85],[86] in tabulating the data that support the aspect of a green marketing tourism (Duffett et al., 2018; López-Rodríguez, 2016; Mokha, 2017; Moravcikova, Krizanova, Kliestikova, \& Rypakova, 2017). [87],[88].

\section{Finding and discussion}

Table 2 Tabulated data

\begin{tabular}{|l|l|l|l|l|l|}
\hline Destination & $S I$ & $P E B$ & $E C$ & $A P E B$ & Score \\
\hline $\begin{array}{l}\text { Breathtaking } \\
\text { Belum }\end{array}$ & 0.69 & 0.79 & 0.79 & 0.76 & 0.758 \\
\hline Bukit Larut & 0.74 & 0.76 & 0.78 & 0.73 & 0.753 \\
\hline Teluk Batik & 0.78 & 0.73 & 0.68 & 0.72 & 0.728 \\
\hline $\begin{array}{l}\text { Pangkor } \\
\text { Island }\end{array}$ & 0.74 & 0.70 & 0.72 & 0.71 & 0.718 \\
\hline $\begin{array}{l}\text { Pasir Bogak } \\
\text { Beach }\end{array}$ & 0.75 & 0.71 & 0.70 & 0.70 & 0.715 \\
\hline
\end{tabular}

Note: $\mathrm{SI}=$ Social Influence; $\mathrm{PEB}=$ Pro-environmental behavior; $\mathrm{EC}=$ Environmental Concern; and $\mathrm{APEB}=$ Awareness and pro-environmental behavior

\subsection{Breathtaking Belum}

This study indicated that Breathtaking Belum is the best destination (Table 2), for fulfilling green marketing (score 0.758 ). SI (0.69) indicated the travel cost accommodated the friendly environmental price supporting of green marketing (GM) that spent by tourists. While, EC (0.79) shown by an area (117 500 hectares) of land protected State Park has been confirmed, and this area is only onethird of the protected area in 2007. It supported product of GM. The rest of the other land degraded due to illegal hunting, illegal logging, and deforestation (Silvera, Lavack, \& Kropp, 2008)[89].

PEB in environmental protection (Fu et al., 2020) 0.79 stating about 10 species of hornbills, 3000 species of 
flowering plants: Rafflesia (Rafflesia Kerrii, Rafflesia Azlanii, and Rafflesia Cantleyii). Moreover, there is 222 birds of conservation. It reflected the distribution of GM. While, The APEB of Breathaking Belum (0.76) indicated the promotion supporting GM. It indicated naturality of jungle promotion as their livelihood

\subsection{Bukit Larut}

SI Bukit Larut (0.74) indicated that the cost of traveling supported the GM in terms eco-friendly. While, EC (0.78) indicated by the decision of the Sultan of Perak sets an area of 300 acre (Zhang et al., 2020) [90] that support the product of green marketing. In 2010, King Silver construct Bukit Larut cable car to develop the on infrastructure and the accessibility of the tourists that want to visit to the top of the hill and in the afternoon, tourists can enjoy the sunset while drinking hot tea.

PEB index (Saifulina, Carballo-Penela, \& RuzoSanmartín, 2020)[91] of 0.76 supporting green place (distribution) of the GM. It reflected by the performance of Forest Hill Late that protects the water catchment. More recently, the conservation area is reduced because a lot of the projects in Bukit Larut. Nevertheless, APEB index (Fu et al., 2020) 0.73 supporting the promotion of the GM. It reflected to the Sultan of Perak matched to green marketing support.

\subsection{Teluk Batik}

SI index (Zimmermann, 2020)[92] 0.78, represented fair cost of green marketing that tourists spent their money matched with they consumed. It supporting the price of the GM. While, PEB index (Quoquab, Mohammad, \& Shahrin, 2020b)[93] 0.73 supporting green place (distribution) of the GM. It indicated the cleanliness of the destination that supported place or distribution of green marketing. While, EC Index 0.68 supporting reflected at the nickname of Teluk Batik beach which has pearl white beaches and the long sandy beach, with some 300 species of sea shells in the museum shells. Green tourism activities that can be carried by tourists such as swimming, recreation, enjoying sea landscape, snorkeling, diving underwater world, village survival, trekking trail, souvenirs, and enjoy the beach Sunset at Teluk Batik.

APEB index (Fu et al., 2020) 0.72 shows that it supported green place (distribution) of GM. It indicated the availability of green tourism activities in Teluk Batik. It provides a variety of environmentally friendly swimming activity and with the involvement of a number of 150 vocational students and teachers take part in creating green coastal tourism by cleaning trash around the beach Teluk Batik.

\subsection{Pangkor island}

SI index (Roethke et al., 2020)[32] of 0.74 indicates that tourism activity in Pangkor island provided with friendly price. It has historical value, because Pangkor island 17th century has been a strategic place for fishermen, sailors, and merchants, in their efforts to control trading activities in the Strait of Melaka. In the eastern part of the island of Pangkor is located Fishing Village where tourists can do fishing tourism.

PEB index (Vicente-Molina, Fernández-Sainz, \& Izagirre-Olaizola, 2018)[94] 0.70 shows it supporting distribution of the GM. It reflected in Pangkor island there are many gathering place for fishermen, sailors, and merchants as fishing activities too (Kautish \& Sharma, 2020b). Pangkor Island became an important place in the control of trading activities in the Strait of Melaka. On the island of Pangkor, there is also a fort established by the Dutch when they perform activities in Perak tin trade monopoly.

EC Index 0.72 shows that the performance of beach tourism in Pangkor Island based on environmental care is quite high. It supporting the product of the GM. During the program of the visit Perak tourism in 2012, Pangkor Island is visited by 1.3 million tourists

APEB index of (Fu et al., 2020) 0.71 indicating it supporting the promotion of the GM. It reflected Perak state government's decision to promote tourist destinations in the entire Perak as one of the main tourist destinations in Malaysia. At the same time Japanese tourists also advised governments Perak duly perform marketing green tourism by promoting green tourism more aggressively among international tourists to visit the island of Pangkor in the future. Pangkor Island has a beautiful beach and has the calmest sea, and tourists can travel around Pangkor Island by ferry. Pangkor island tourists can also observe the feeding activity of birds Hornbi.

\subsection{Pasir Bogak Beaches}

SI index (Pan et al., 2020b) 0.75. It's indicated that Pasir Bogak Beach Supporting price of the GM. While, PEB index 0.71 reflected by the performance of distribution of the GM. It has clear sea water and white sand along the beach.

EC index (Wu \& Hou, 2020)[95] 0.70 reflected by the performance of the green-coastal tourism product of the Pasir Bogak. It has a white sand beaches and has a shallow and crystal-clear sea water as well. Green tourism attraction in the beach of Pasir Bogak for tourists is like observe the feeding activity of the Hornbill bird.

APEB index (Gabarda-Mallorquí et al., 2018) of 0.70 is supporting the promotion of the GM. It shown by the awareness actions of the local government to promote and preparing the quality of the landscape in the region and encourage the development of conservation areas around the beach Pasir Bogak. They organize, and manage vegetation on private property, identify and preserve the visual landscape of the highlands. Besides, they preserved natural scenery in the area of the development, and integrate with natural scenic.

However, based on research results and discussion indicate that green marketing strategy ready applying in the area of Breathaking Belum, Bukit Larut, Teluk Batik, Pangkor Island, and Pasir Bogak. Breathaking Belum has limited performance in SI index (0.69). This means that the destination required more support from tourists, tour 
operators, and local governments to strengthen their influence in environmental awareness program marketing green tourism (Saari, Fritz, Mäkinen, \& Baumgartner, 2018) [96].

\subsection{Proposed Developing Green Marketing Tourism model}

Moreover, we proposed green marketing tourism model to conduct at from above destination (Figure 1)

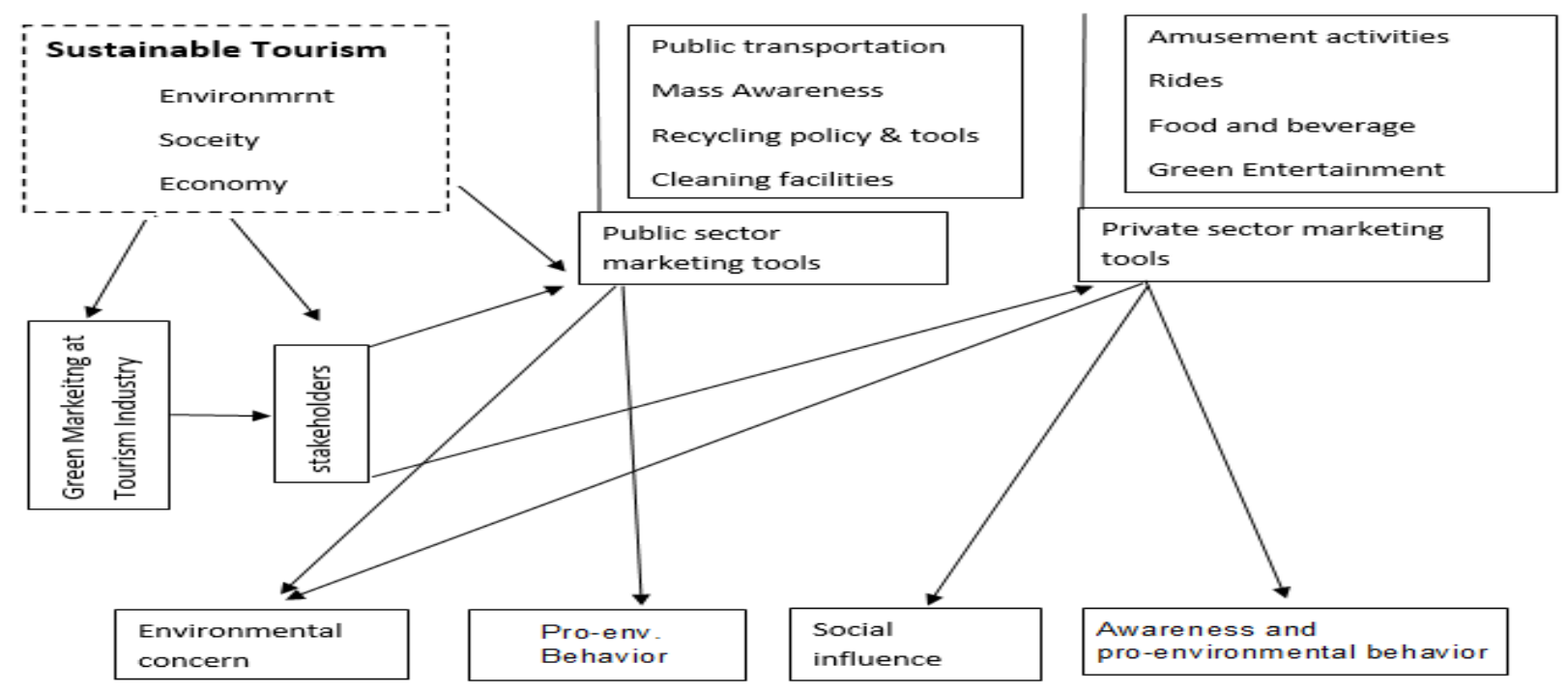

Figure 1: Proposed green marketing tourism model for Perak

The above proposed model is executable for the authority. As we can see the whole process should be taken in action considering the sustainable tourism. Sustainable tourism should be comprising benefit towards environment, economy and the society of the particular region. The model is the first step should be confirming the green marketing at tourism industry. There could be a governing body to execute and monitor the whole process (Chin, Chin, \& Wong, 2018; Saari et al., 2018)[97],[98]. under that governing body there are some stake holders who are responsible to maintain the public and privet sector marketing tools. Even though private sector has some liabilities for environment but it largely depends on public sector. the government and other related associate should be responsible for maintaining that. Public sector also should use their marketing tools to create a proenvironment behavior (Gabarda-Mallorquí et al., 2018). Besides there are private sectors who are responsible for creating the social influence and awareness and proenvironmental behavior (Fu et al., 2020).

Public sector marketing tools are not limited to but including public transportation, creating mass awareness, recycling policy and cleaning mechanism. These interests will do a lot favor to protect the environment towards sustainable goal. Concerning body must take fruitful steps to implement and follow up for continuous basis. On the other side, private sector marketing mechanisms includes amusement activities for the tourists, share rides, food and beverages that ensure disposable packaging and green entertainment for the visitors.

\section{Conclusion}

Referring to the findings and discussion of this study revealed from five tourism destinations in Perak is ready to implement green tourism marketing programs as a starting point to support green marketing strategy. They would start implementing green tourism marketing strategy in Perak soon. The program can respond to the expectations of NGOs.

The study found fore-mention destinations ready applying green marketing. On the one hand, most of the respondents stated that Teluk Batik is the strongest in it as local community empowerment in the SI context. On the other hand, referred to $\mathrm{PEB}$, it has indicated that distribution of Breathtaking Belum's environment is well protecting. While, referred to the context of EC, most of the respondents mentioned that Breathtaking Belum is the most concern to the environment that supported the product of the GM. With regards for APEB, majority of respondents considered that the destination Breathtaking Belum has the most effective promotion for supporting the GM program.

Therefore, the research outcomes suggest the State Government of Perak preparing to amend the State Forest Act on tackling further environmental destruction. The formation of green tourism marketing in several locations in Perak, also can support the effort to address the environmental damage tourism, as well as tour guides and tour operators in the use of the environment for green tourism destination.

\section{Reference:}

1. Tong, G. (2020, February 4). Gov't to focus on new tourism markets after sharp decline in China tourists. Retrieved June 19, 2020, from https://www.malaysiakini.com/news/509504

2. Hays, J. (2015, June). FIRES AND ENVIRONMENTAL ISSUES IN MALAYSIA | 
Facts and Details. Retrieved June 17, 2020, from http://factsanddetails.com/southeastasia/Malaysia/sub5 4e/entry-3704.html

3. JAG. (2011, September). Perak Tourism Bhd Appoints CEO. Retrieved June 16, 2020, from http://www.ipohecho.com.my/v2/2011/09/02/peraktourism-bhd-appoints-ceo/

4. Farsa. (2012, November). Pelancongan Kini Malaysia (Malaysia - Tourism Now): November 2012. Retrieved June 16, 2020, from http://pelancongan-

kini.blogspot.com/2012 1101 archive.html

5. Dangelico, R. M., \& Vocalelli, D. (2017a). "Green Marketing": An analysis of definitions, strategy steps, and tools through a systematic review of the literature. Journal of Cleaner Production, 165, 1263-1279. https://doi.org/10.1016/J.JCLEPRO.2017.07.184

6. Duffett, R., Edu, T., Haydam, N., Negricea, I.-C., \& Zaharia, R. (2018). A Multi-Dimensional Approach of Green Marketing Competitive Advantage: A Perspective of Small Medium and Micro Enterprises from Western Cape, South Africa. Sustainability, 10(10), 3764. https://doi.org/10.3390/su10103764

7. Groening, C., Sarkis, J., \& Zhu, Q. (2018). Green marketing consumer-level theory review: A compendium of applied theories and further research directions. Journal of Cleaner Production, 172, 18481866.

https://doi.org/10.1016/J.JCLEPRO.2017.12.002

8. Nedumaran, G., \& M, M. (2020). Green Marketing on Customer Behaviour Towards Usage of Green Products. SSRN Electronic Journal. https://doi.org/10.2139/ssrn.3551990

9. Rahbar, E., \& Wahid, N. A. (2011). Investigation of green marketing tools' effect on consumers' purchase behavior. Business Strategy Series, 12(2), 73-83. https://doi.org/10.1108/17515631111114877

10. Szabo, S., \& Webster, J. (2020). Perceived Greenwashing: The Effects of Green Marketing on Environmental and Product Perceptions. Journal of Business Ethics, 1-21. https://doi.org/10.1007/s10551-020-04461-0

11. Tsai, P. H., Lin, G. Y., Zheng, Y. L., Chen, Y. C., Chen, P. Z., \& Su, Z. C. (2020). Exploring the effect of Starbucks' green marketing on consumers'

12. purchase decisions from consumers' perspective. Journal of Retailing and Consumer Services, 56, 102162. https://doi.org/10.1016/j.jretconser.2020.102162

13. Cui, L., Guo, S., \& Zhang, H. (2020). Coordinating a Green Agri-Food Supply Chain with RevenueSharing Contracts Considering Retailers' Green Marketing Efforts. Sustainability, 12(4), 1289. https://doi.org/10.3390/su12041289

14. Khan, E. A., Royhan, P., Rahman, M. A., Rahman, M. M., \& Mostafa, A. (2020). The impact of enviropreneurial orientation on small firms' business performance: The mediation of green marketing mix and eco-labeling strategies. Sustainability (Switzerland), 12(1), https://doi.org/10.3390/SU12010221
15. Papadas, K.-K., Avlonitis, G. J., \& Carrigan, M. (2017). Green marketing orientation: Conceptualization, scale development and validation. Journal of Business Research, 80, 236-246. https://doi.org/10.1016/J.JBUSRES.2017.05.024

16. Papadopoulos, I., Karagouni, G., Trigkas, M., \& Platogianni, E. (2010). Green marketing the case of greece in certified and sustainably managed timber products. EuroMed Journal of Business, 5(2), 166190. https://doi.org/10.1108/14502191011065491

17. Stafford, E. R., \& Graul, A. R. H. (2020). Turning Consumers Green: From Green Marketing Myopia to Our 2020 Vision. Sustainability, 13(1), 10-21. https://doi.org/10.1089/sus.2020.29178.ers

18. Syaekhoni, M., Alfian, G., \& Kwon, Y. (2017). Customer Purchasing Behavior Analysis as Alternatives for Supporting In-Store Green Marketing Decision-Making. Sustainability, 9(11), 2008. https://doi.org/10.3390/su9112008

19. Dangelico, R. M., \& Vocalelli, D. (2017b, November 1). "Green Marketing": An analysis of definitions, strategy steps, and tools through a systematic review of the literature. Journal of Cleaner Production. Elsevier https://doi.org/10.1016/j.jclepro.2017.07.184

20. Mokha, A. K. (2017). Green Marketing: A Study of Consumer Perception on using Eco-Friendly Products. Asian Journal of Research in Business Economics and Management, 7(8), 298. https://doi.org/10.5958/2249-7307.2017.00146.3

21. Mukonza, C., \& Swarts, I. (2020). The influence of green marketing strategies on business performance and corporate image in the retail sector. Business Strategy and the Environment, 29(3), 838-845. https://doi.org/10.1002/bse. 2401

22. Singh, P., Singh, R., \& Sharma, S. (2016). Emergence of Green marketing Strategies and Sustainable Development in India. Journal of Commerce and Management Thought, 7(4), 693.https://doi.org/10.5958/0976478x.2016.00037.9

23. Argo, J. J., \& Dahl, D. W. (2020). Social Influence in the Retail Context: A Contemporary Review of the Literature. Journal of Retailing, 96(1), 25-39. https://doi.org/10.1016/j.jretai.2019.12.005

24. Higgs, S., \& Ruddock, H. (2020). Social Influences on Eating. In Handbook of Eating and Drinking (pp. 277-291). Springer International Publishing. https://doi.org/10.1007/978-3-030-14504-0_27

25. Hsu, C. L., \& Lin, J. C. C. (2008). Acceptance of blog usage: The roles of technology acceptance, social influence and knowledge sharing motivation. Information and Management, 45(1), 65-74. https://doi.org/10.1016/j.im.2007.11.001

26. Baumann, F., Lorenz-Spreen, P., Sokolov, I. M., \& Starnini, M. (2020). Modeling Echo Chambers and Polarization Dynamics in Social Networks. Physical Review Letters, 124(4), 048301. https://doi.org/10.1103/PhysRevLett.124.048301

27. Koskinen, J., \& Daraganova, G. (2020). Bayesian Analysis of Social Influence. Retrieved from http://arxiv.org/abs/2006.16464 
28. Meoli, A., Fini, R., Sobrero, M., \& Wiklund, J. (2020). How entrepreneurial intentions influence entrepreneurial career choices: The moderating influence of social context. Journal of Business Venturing, $\quad 35(3), \quad 105982$. https://doi.org/10.1016/j.jbusvent.2019.10598

29. Muthukrishna, M., \& Schaller, M. (2020). Are Collectivistic Cultures More Prone to Rapid Transformation? Computational Models of CrossCultural Differences, Social Network Structure, Dynamic Social Influence, and Cultural Change. Personality and Social Psychology Review, 24(2), 103-120. https://doi.org/10.1177/1088868319855783

30. Ni, C., Yang, J., \& Kong, D. (2020). Sequential seeding strategy for social influence diffusion with improved entropy-based centrality. Physica A: Statistical Mechanics and Its Applications, 545, 123659. https://doi.org/10.1016/j.physa.2019.123659

31. Pan, Y., He, F., \& Yu, H. (2020a). A correlative denoising autoencoder to model social influence for top-N recommender system. Frontiers of Computer Science, 14(3), 1-13. https://doi.org/10.1007/s11704019-8123-3

32. Ramos, G., Boratto, L., \& Caleiro, C. (2020). On the negative impact of social influence in recommender systems: A study of bribery in collaborative hybrid algorithms. Information Processing and Management, $57(2)$, 102058. https://doi.org/10.1016/j.ipm.2019.102058

33. Roethke, K., Klumpe, J., Adam, M., \& Benlian, A. (2020). Social influence tactics in e-commerce onboarding: The role of social proof and reciprocity in affecting user registrations. Decision Support Systems, $131, \quad 113268$. https://doi.org/10.1016/j.dss.2020.113268

34. Singh, N., Sinha, N., \& Liébana-Cabanillas, F. J. (2020). Determining factors in the adoption and recommendation of mobile wallet services in India: Analysis of the effect of innovativeness, stress to use and social influence. International Journal of Information Management, 50, 191-205. https://doi.org/10.1016/j.ijinfomgt.2019.05.022

35. Weiß, M., Mussel, P., \& Hewig, J. (2020). The value of a real face: Differences between affective faces and emojis in neural processing and their social influence on decision-making. Social Neuroscience, 15(3), 255-268.

https://doi.org/10.1080/17470919.2019.1675758

36. Young, H. P. (2009). Innovation diffusion in heterogeneous populations: Contagion, social influence, and social learning. American Economic Review, 99(5), 1899-1924. https://doi.org/10.1257/aer.99.5.1899

37. Efferson, C., Vogt, S., \& Fehr, E. (2020). The promise and the peril of using social influence to reverse harmful traditions. Nature Human Behaviour, $4(1), \quad 55-68 . \quad$ https://doi.org/10.1038/s41562-0190768-2

38. Pan, Y., He, F., \& Yu, H. (2020b). A correlative denoising autoencoder to model social influence for top-N recommender system. Frontiers of Computer
Science, 14(3), 1-13. https://doi.org/10.1007/s11704019-8123-3

39. Abu-Salih, B., Chan, K. Y., Al-Kadi, O., Al-Tawil, M., Wongthongtham, P., Issa, T., ... Albahlal, A. (2020). Time-aware domain-based social influence prediction. Journal of Big Data, 7(1), 1-37. https://doi.org/10.1186/s40537-020-0283-3

40. Chouchani, N., \& Abed, M. (2020). Enhance sentiment analysis on social networks with social influence analytics. Journal of Ambient Intelligence and Humanized Computing, 11(1), 139-149. https://doi.org/10.1007/s12652-019-01234-0

41. Bian, J., Zhang, G., \& Zhou, G. (2020a). Manufacturer vs. Consumer Subsidy with Green Technology Investment and Environmental Concern. European Journal of Operational Research, 287(3), 832-843. https://doi.org/10.1016/j.ejor.2020.05.014

42. Bourliva, A., Papadopoulou, L., da Silva, E. F., \& Patinha, C. (2020). In vitro assessment of oral and respiratory bio-accessibility of trace elements of environmental concern in Greek fly ashes: Assessing health risk via ingestion and inhalation. Science of the Total Environment, 704, 135324. https://doi.org/10.1016/j.scitotenv.2019.135324

43. Campos-Soria, J. A., Núñez-Carrasco, J. A., \& García-Pozo, A. (2020). Environmental Concern and Destination Choices of Tourists: Exploring the Underpinnings of Country Heterogeneity. Journal of Travel Research, 004728752093368. https://doi.org/10.1177/0047287520933686

44. Chuah, S. H. W., El-Manstrly, D., Tseng, M. L., \& Ramayah, T. (2020). Sustaining customer engagement behavior through corporate social responsibility: The roles of environmental concern and green trust. Journal of Cleaner Production, 262, 121348. https://doi.org/10.1016/j.jclepro.2020.121348

45. Hao, F., \& Song, L. (2020). Environmental Concern in China: A Multilevel Analysis. Chinese Sociological Review, 52(1), 1-26. https://doi.org/10.1080/21620555.2019.1654367

46. Harmooshi, N. N., Shirbandi, K., \& Rahim, F. (2020, June 26). Environmental concern regarding the effect of humidity and temperature on 2019-nCoV survival: fact or fiction. Environmental Science and Pollution Research. Springer. https://doi.org/10.1007/s11356020-09733-w

47. Kim, J., Tanaka, H. S., \& Schmöcker, J. D. (2020). Joint car ownership and car type preference model considering engagement in online activities and environmental concern. Transportation Research Part F: Traffic Psychology and Behaviour, 68, 293-305. https://doi.org/10.1016/j.trf.2019.11.012

48. Milfont, T. L., Poortinga, W., \& Sibley, C. G. (2020). Does having children increase environmental concern? Testing parenthood effects with longitudinal data from the New Zealand Attitudes and Values Study. PLOS ONE, 15(3), e0230361. https://doi.org/10.1371/journal.pone.0230361

49. Nguyen, G. T. H., Nocentini, A., Angeli, A., Gratteri, P., Supuran, C. T., \& Donald, W. A. (2020). Perfluoroalkyl Substances of Significant 
Environmental Concern Can Strongly Inhibit Human Carbonic Anhydrase Isozymes. Analytical Chemistry, 92(6), 4614-4622. https://doi.org/10.1021/acs.analchem.0c00163

50. Weber, A., Büssing, A. G., Jarzyna, R., \& Fiebelkorn, F. (2020). Do German student biology teachers intend to eat sustainably? Extending the theory of planned behavior with nature relatedness and environmental concern. Sustainability (Switzerland), 12(12), 4909. https://doi.org/10.3390/SU12124909

51. Yang, G., Ji, G., \& Tan, K. H. (2020). Impact of regulatory intervention and consumer environmental concern on product introduction. International Journal of Production Economics, 107898. https://doi.org/10.1016/j.ijpe.2020.107898

52. Yue, B., Sheng, G., She, S., \& Xu, J. (2020). Impact of Consumer Environmental Responsibility on Green Consumption Behavior in China: The Role of Environmental Concern and Price Sensitivity. Sustainability, $\quad$ 12(5), 2074. https://doi.org/10.3390/su12052074

53. Bian, J., Zhang, G., \& Zhou, G. (2020b). Manufacturer vs. Consumer Subsidy with Green Technology Investment and Environmental Concern. European Journal of Operational Research. https://doi.org/10.1016/j.ejor.2020.05.014

54. Cruz, S. M., \& Manata, B. (2020). Measurement of Environmental Concern: A Review and Analysis. Frontiers in Psychology, 11, 363. https://doi.org/10.3389/fpsyg.2020.00363

55. Franzen, A., \& Mader, S. (2020). Can Climate Skeptics Be Convinced? The Effect of Nature Videos on Environmental Concern. Sustainability, 12(7), 2972. https://doi.org/10.3390/su12072972

56. Rodrigo-Comino, J. (2020). Soil Erosion as an Environmental Concern ... for Everyone? Proceedings, 30(1), 72. https://doi.org/10.3390/proceedings2019030072

57. Ma, H., \& He, G. (2020). How does environmental concern influence public acceptability of congestion charging? Evidence from Beijing. Ecosystem Health and Sustainability, 6(1), 1722033. https://doi.org/10.1080/20964129.2020.1722033

58. Rizkalla, N., \& Erhan, T. P. (2020). Sustainable Consumption Behaviour in The Context of Millennials in Indonesia - Can Environmental Concern, Self-efficacy, Guilt and Subjective Knowledge Make a Difference? Management:Journal of Sustainable Business and Management Solutions in Emerging Economies. https://doi.org/10.7595/MANAGEMENT.FON.2020 .0001

59. Denzin, N. K. (2012). Triangulation 2.0 . Journal of Mixed Methods Research, 6(2), 80-88. https://doi.org/10.1177/1558689812437186

60. Afsar, B., \& Umrani, W. A. (2020). Corporate social responsibility and pro-environmental behavior at workplace: The role of moral reflectiveness, coworker advocacy, and environmental commitment. Corporate Social Responsibility and Environmental Management, 27(1), 109-125. https://doi.org/10.1002/csr.1777
61. Fu, L., Sun, Z., Zha, L., Liu, F., He, L., Sun, X., \& Jing, X. (2020). Environmental awareness and proenvironmental behavior within China's road freight transportation industry: Moderating role of perceived policy effectiveness. Journal of Cleaner Production, 252, 119796. https://doi.org/10.1016/j.jclepro.2019.119796

62. Hamann, K. R. S., \& Reese, G. (2020). My Influence on the World (of Others): Goal Efficacy Beliefs and Efficacy Affect Predict Private, Public, and Activist Pro-environmental Behavior. Journal of Social Issues, 76(1), 35-53. https://doi.org/10.1111/josi.12369

63. Kaaronen, R. O., \& Strelkovskii, N. (2020). Cultural Evolution of Sustainable Behaviors: Proenvironmental Tipping Points in an Agent-Based Model. One Earth, 2(1), 85-97. https://doi.org/10.1016/j.oneear.2020.01.003

64. Kim, M. S., \& Stepchenkova, S. (2020, July 2). Altruistic values and environmental knowledge as triggers of pro-environmental behavior among tourists. Current Issues in Tourism. Routledge. https://doi.org/10.1080/13683500.2019.1628188

65. Shafiei, A., \& Maleksaeidi, H. (2020). Proenvironmental behavior of university students: Application of protection motivation theory. Global Ecology and Conservation, 22, e00908. https://doi.org/10.1016/j.gecco.2020.e00908

66. Vesely, S., Klöckner, C. A., \& Brick, C. (2020). Proenvironmental behavior as a signal of cooperativeness: Evidence from a social dilemma experiment. Journal of Environmental Psychology, 67 ,

https://doi.org/10.1016/j.jenvp.2019.101362 101362.

67. Xu, F., Huang, L., \& Whitmarsh, L. (2020). Home and away: cross-contextual consistency in tourists' pro-environmental behavior. Journal of Sustainable Tourism, 28(10), 1443-1459. https://doi.org/10.1080/09669582.2020.1741596

68. Binder, M., Blankenberg, A. K., \& Guardiola, J. (2020). Does it have to be a sacrifice? Different notions of the good life, pro-environmental behavior and their heterogeneous impact on well-being. Ecological Economics, 167, 106448. https://doi.org/10.1016/j.ecolecon.2019.106448

69. Chwialkowska, A., Bhatti, W. A., \& Glowik, M. (2020). The influence of cultural values on proenvironmental behavior. Journal of Cleaner Production, 268, 122305. https://doi.org/10.1016/j.jclepro.2020.122305

70. Cleveland, M., Robertson, J. L., \& Volk, V. (2020). Helping or hindering: Environmental locus of control, subjective enablers and constraints, and proenvironmental behaviors. Journal of Cleaner Production, 249, 119394. https://doi.org/10.1016/j.jclepro.2019.119394

71. Gong, X., Zhang, J., Zhang, H., Cheng, M., Wang, F., \& Yu, N. (2020). Internet use encourages proenvironmental behavior: Evidence from China. Journal of Cleaner Production, 256, 120725. https://doi.org/10.1016/j.jclepro.2020.120725

72. Hoffmann, R., \& Muttarak, R. (2020). Greening through schooling: Understanding the link between 
education and pro-environmental behavior in the Philippines. Environmental Research Letters, 15(1), 014009. https://doi.org/10.1088/1748-9326/ab5ea0

73. Kautish, P., \& Sharma, R. (2020a). Determinants of pro-environmental behavior and environmentally conscious consumer behavior: An empirical investigation from emerging market. BUSINESS STRATEGY \& DEVELOPMENT, 3(1), 112-127. https://doi.org/10.1002/bsd2.82

74. Lee, P.-S., Sung, Y.-H., Wu, C.-C., Ho, L.-C., \& Chiou, W.-B. (2020). Using Episodic Future Thinking to Pre-Experience Climate Change Increases Pro-Environmental Behavior. Environment and Behavior, 52(1), 60-81. https://doi.org/10.1177/0013916518790590

75. Liobikienè, G., Liobikas, J., Brizga, J., \& Juknys, R. (2020). Materialistic values impact on proenvironmental behavior: The case of transition country as Lithuania. Journal of Cleaner Production, 244 , https://doi.org/10.1016/j.jclepro.2019.118859

118859.

76. Quoquab, F., Mohammad, J., \& Shahrin, R. (2020a). Pro-environmental behavior in nutricosmetics product purchase context: Scale development and validation. International Journal of Pharmaceutical and Healthcare Marketing, 14(2), 217-250. https://doi.org/10.1108/IJPHM-04-2019-0033

77. Wong, I. K. A., Wan, Y. K. P., Huang, G. Q. I., \& Qi, S. (2020). Green event directed pro-environmental behavior: an application of goal systems theory. Journal of Sustainable Tourism. https://doi.org/10.1080/09669582.2020.1770770

78. Yuriev, A., Dahmen, M., Paillé, P., Boiral, O., \& Guillaumie, L. (2020, April 1). Pro-environmental behaviors through the lens of the theory of planned behavior: A scoping review. Resources, Conservation and Recycling. Elsevier B.V. https://doi.org/10.1016/j.resconrec.2019.104660

79. Zibarras, L. D., \& Coan, P. (2015). HRM practices used to promote pro-environmental behavior: a UK survey. International Journal of Human Resource Management, 26(16), 2121-2142. https://doi.org/10.1080/09585192.2014.972429

80. Gabarda-Mallorquí, A., Fraguell, R., \& Ribas, A. (2018). Exploring Environmental Awareness and Behavior among Guests at Hotels That Apply WaterSaving Measures. Sustainability, 10(5), 1305. https://doi.org/10.3390/su10051305

81. Chen, Y., \& Cai, D. (2019). Ant Forest through the Haze: A Case Study of Gamified Participatory ProEnvironmental Communication in China. J, 2(4), 467-479. https://doi.org/10.3390/j2040030

82. Dopelt, K., Radon, P., \& Davidovitch, N. (2019). Environmental Effects of the Livestock Industry: The Relationship between Knowledge, Attitudes, and Behavior among Students in Israel. International Journal of Environmental Research and Public Health, 16(8), 1359. https://doi.org/10.3390/ijerph16081359

83. Nyumba, T., Wilson, K., Derrick, C. J., \& Mukherjee, N. (2018). The use of focus group discussion methodology: Insights from two decades of application in conservation. Methods in Ecology and
Evolution, 9(1), 20-32. https://doi.org/10.1111/2041210X.12860

84. Archibald, M. M. (2016). Investigator Triangulation. Journal of Mixed Methods Research, 10(3), 228-250. https://doi.org/10.1177/1558689815570092

85. Hengky, S. H. (2015). Image Analysis: Textile Industry in Indonesia. World Journal of Business and Management, 1(1), 42-56. https://doi.org/https://doi.org/10.5296/wjbm.v1i1.78 83

86. Tiggemann, M., \& Zaccardo, M. (2018). 'Strong is the new skinny': A content analysis of \#fitspiration images on Instagram. Journal of Health Psychology, 23(8), 1003-1011. https://doi.org/10.1177/1359105316639436

87. Vaismoradi, M., Turunen, H., \& Bondas, T. (2013). Content analysis and thematic analysis: Implications for conducting a qualitative descriptive study. Nursing \& Health Sciences, 15(3), 398-405. https://doi.org/10.1111/nhs. 12048

88. López-Rodríguez, S. (2016). GREEN MARKETING AND A BROADER STAKEHOLDER ORIENTATION. Academy of Marketing Studies Journal (Vol. 20).

89. Moravcikova, D., Krizanova, A., Kliestikova, J., \& Rypakova, M. (2017). Green Marketing as the Source of the Competitive Advantage of the Business. Sustainability, $\quad 9(12), \quad 2218$. https://doi.org/10.3390/su9122218

90. Silvera, D. H., Lavack, A. M., \& Kropp, F. (2008). Impulse buying: The role of affect, social influence, and subjective wellbeing. Journal of Consumer Marketing, 25(1), 23-33. https://doi.org/10.1108/07363760810845381

91. Zhang, T., Tao, D., Qu, X., Zhang, X., Zeng, J., Zhu, H., \& Zhu, H. (2020). Automated vehicle acceptance in China: Social influence and initial trust are key determinants. Transportation Research Part C: Emerging Technologies, 112, 220-233. https://doi.org/10.1016/j.trc.2020.01.027

92. Saifulina, N., Carballo-Penela, A., \& RuzoSanmartín, E. (2020). Sustainable HRM and Green HRM: The Role of Green HRM in Influencing Employee Pro-environmental Behavior at Work. https://doi.org/10.20900/jsr20200026

93. Zimmermann, T. (2020). Social Influence or Rational Choice? Two Models and Their Contribution to Explaining Class Differentials in Student Educational Aspirations. European Sociological Review, 36(1), 65-81. https://doi.org/10.1093/esr/jcz054

94. Quoquab, F., Mohammad, J., \& Shahrin, R. (2020b). Pro-environmental behavior in nutricosmetics product purchase context: Scale development and validation. International Journal of Pharmaceutical and Healthcare Marketing. https://doi.org/10.1108/IJPHM-04-2019-0033

95. Vicente-Molina, M. A., Fernández-Sainz, A., \& Izagirre-Olaizola, J. (2018). Does gender make a difference in pro- environmental behavior? The case of the Basque Country University students. Journal of Cleaner Production, 176, 89-98. https://doi.org/10.1016/j.jclepro.2017.12.079 
96. Wu, H., \& Hou, H. (2020). Environmental Concern, Green Purchase Intention and Customers' Perceived Green Building Design. The 26th Pacific Rim Real Estate Society Annual Conference.

97. Saari, U. A., Fritz, M. M. C., Mäkinen, S. J., \& Baumgartner, R. J. (2018). Designing Green Marketing Across Industries: A Conceptual Framework and Implications for Consumers and Transdisciplinary Research (pp. 581-596). Springer, Cham. https://doi.org/10.1007/978-3-319-63007636

98. Chin, C.-H., Chin, C.-L., \& Wong, W. P.-M. (2018). The Implementation of Green Marketing Tools in Rural Tourism: The Readiness of Tourists? Journal of Hospitality Marketing \& Management, 27(3), 261280.

https://doi.org/10.1080/19368623.2017.1359723 